\title{
The dual life of embedded CPs: Evidence from Russian čto-clauses*
}

\author{
Tatiana Bondarenko \\ Massachusetts Institute of Technology
}

\begin{abstract}
With the data from clauses with the complementizer čto in Russian, I argue that embedded finite clauses with the same morphosyntactic appearance can receive two different denotations depending on the argument that they modify. I show that čto-clauses can combine with both nouns like mysl' 'thought' and nouns like situacija 'situation', and that they do not have the same interpretation in these two cases. I propose that when čto-clauses combine with predicates of contentful individuals (like mysl' 'thought'), they describe the propositional content that these individuals have (Moltmann 1989, Kratzer 2006, Moulton 2015, a.o.). However when they combine with predicates of situations (like situacija 'situation'), they provide the proposition that these situations exemplify. I furthermore show that the two meanings of čto-clauses can be detected when they occur with verbs as well, and sketch out a more decompositional view of how the two interpretations arise based on comparison with -(n)un-clauses that modify nouns in Korean.
\end{abstract}

Keywords: clausal embedding, attitude reports, Russian, Korean, situation semantics

\section{Introduction}

This paper is concerned with the question of what kinds of objects we find in the denotations of finite embedded clauses. For example, here are some candidates that we might consider as the meaning of the clause that the squirrels ate the nuts:

$\llbracket$ that the squirrels ate the nuts $\rrbracket=$ ?

a. $\{s:$ the squirrels ate the nuts in $s\}$

b. $\{\mathrm{s}: \mathrm{s}$ is a minimal situation of the squirrels eating the nuts $\}$

c. $\left\{x:\right.$ Content $(x)=\left\{s^{\prime}:\right.$ the squirrels ate the nuts in $\left.\left.s^{\prime}\right\}\right\}$

* I am indebted to my Russian consultants, especially to Misha Berežkov, Lena Delikanova, Nastya Gruzdeva, Anton Kukhto, Mitya Privoznov, and Nadya Voronova, and to Eunsun Jou for Korean judgements. I am very grateful for helpful discussions to Patrick Elliott, Kai von Fintel, Danny Fox, Sabine Iatridou, Florian Schwarz, Roger Schwarzschild, participants of LFRG at MIT and SALT 31 at Brown University, and to the anonymous reviewers of SALT. All errors are my own. 
In (1a) the meaning of the $\mathrm{CP}$ is the set of situations (of all sizes) in which the squirrels ate the nuts. (1b) hypothesizes that the denotation of the CP is the set of minimal situations of the squirrels eating the nuts, and (1c) proposes to view it as a set of objects with propositional content (Moltmann 1989, Kratzer 2006, Moulton 2015 , a.o.) whose content is equated with the embedded proposition.

In this paper I search for empirical reasons to choose between the options in (1a)-(1c), and argue that finite embedded clauses can have denotations both like in (1b) and like in (1c). Evidence for this view will come from looking at Russian finite embedded clauses with the complementizer $\check{c} t o$. These clauses are the basic complementation strategy that we find in attitude reports like in (2).

(2) Ja dumaju /znaju /pomnju [čto belki s"eli vse orexi].

I think/know/remember COMP squirrels ate all nuts

'I think /know /remember that squirrels ate all the nuts.'

But in addition to verbs, čto-clauses can combine with at least two types of nouns, and those kinds of sentences will be the focus of this paper. The first type of nouns that čto-clauses can combine with are content nouns like mysl' 'thought' or ideja 'idea' (henceforth Cont-DPs), (3): these nouns denote entities that have some propositional content associated with them. The second type are what I will call situation nouns (henceforth Sit-DPs)—nouns like situacija 'situation' or slučaj 'event, occurence' which denote events or states of affairs (4).

Mne prišla v golovu mysl' [čto belki s"eli vse orexi]. to.me arrived in head thought COMP squirrels ate all nuts

'I had a thought that squirrels ate all the nuts.'

(4) Na prošloj nedele byl slučaj [čto belki s"eli vse orexi]. on last week was event COMP squirrels ate all nuts.

'Last week there was an event of squirrels eating all the nuts.'

As we can see, the CPs in (3) and (4) look morphosyntactically the same (and also identical to the CP in (2)), however we will see that their meaning is not identical.

Embedded clauses that combine with Cont-DPs (henceforth Cont-CPs) have been discussed quite extensively in the literature (Stowell 1981; Moltmann 1989; Kratzer 2006; Moulton 2009; Moltmann 2013, 2014; Moulton 2015; Kratzer 2016; Elliott 2016, 2017; Moltmann 2020; Roberts 2020; Srinivas \& Legendre 2020), often in the process of arguing for semantics like in (1c). Clauses that combine with Sit-DPs (henceforth Sit-CPs) received almost no attention in the literature, with the notable exception of Moltmann (2021) discussing the semantics of constructions with the noun 'case'. She argues that NPs like case quantify over situations that are truthmakers of the CP, which is similar to what I propose about CPs with Sit-DPs. 
In this paper I adopt the situation semantics framework (Barwise 1981; Kratzer 1989, 2002, 2020), and argue that embedded finite clauses are predicates whose meaning depends on the argument that they modify (5): if their argument $\mathrm{x}$ has content, the $\mathrm{CP}$ will describe it; but if $\mathrm{x}$ is a situation without content, then the $\mathrm{CP}$ will describe what kind of a situation it is.

$$
\begin{aligned}
& \text { 【that squirrels ate } \rrbracket= \\
& \lambda \mathrm{x} . \begin{cases}\operatorname{Cont}(\mathrm{x})=\left\{\mathrm{s}^{\prime}: \text { squirrels ate in } \mathrm{s}^{\prime}\right\} & x \text { has Content } \\
\mathrm{x} \text { is a minimal squirrel-eating situation } & x \in D_{s} \wedge \text { has no Content } \\
\text { undefined otherwise } & \end{cases}
\end{aligned}
$$

The paper is structured as follows. Section 2 argues for viewing Russian čto-clauses that combine with nouns as modifiers. Section 3 shows that the denotation of čtoclauses when they combine with Cont-DPs cannot be identical to their denotation when they combine with Sit-DPs. In section 4 I present my proposal and discuss how it captures the properties of čto-clauses. Section 5 argues that the same two meanings of čto-clauses that we observe with nouns also exist when these clauses combine with verbs. Section 6 addresses the question of whether the meaning for the complementizer that I provide can be decomposed into several distinct pieces, and suggests that the answer is positive based on comparison of Russian čto-clauses to Korean clauses with the adnominal marker $-(n) u n$. Section 7 concludes the paper.

\section{Embedded čto-clauses are modifiers}

There are at least three reasons to think that čto-clauses are modifiers to nouns. First, they are optional and can be freely omitted, as illustrated in (6a)-(6b).

a. Lena raspustila ètot slux (čto kto-to polučit bol'šuju premiju). Lena spread this rumor (COMP someone will.get big bonus) 'Lena spread this rumor (that someone will get a big bonus).'

b. Lena vspomnila zabavnyj slučaj (čto korova podošla k Lena remembered funny event (COMP cow came to umyval'niku i s"ela naše mylo). wash.basin and ate our soap)

'Lena remembered a funny event (that a cow came to the wash basin and ate our soap).'

Second, they do not have the morphosyntax that clausal arguments have. Arguments to DPs in Russian must bear genitive case, and when a CP is an argument of a DP it has to surface with a genitive form of the demonstrative tot 'that' (7). ${ }^{1}$

1 See Knyazev (2016) for the claim that oblique cases like genitive must be overtly realized in Russian. 
The dual life of embedded CPs

aspekty *(togo) čto načalas' èpoxa Èllinizma aspects that.GEN COMP began period Hellenism 'aspects of (the fact) that the Hellenistic time began.'

Neither Cont-CPs nor Sit-CPs can occur with such a demonstrative:

a. Mnenie (*togo) [čto belki vpadajut v spjačku] ošibočno. opinion (that.GEN) COMP squirrels fall in hibernation mistaken

'The opinion that squirrels hibernate is mistaken.'

b. Složilas' takaja situacija (*togo) [čto ja utopil svoj telefon]. developed such situation (that.GEN) COMP I sunk self's phone

'A situation that I sunk my phone happened.'

Finally, modifiers differ from arguments in being able to undergo Late Merge (Lebeaux 1991). As (9) shows, both Cont-CPs and Sit-CPs can be late-merged to the nouns they combine with and thus avoid a Principle $\mathrm{C}$ violation.

(9) Slux $_{2} /$ slučaj $_{2},[C P$ čto Nadja 1 lečila pacienta, kotoryj otkazyvalsja rumor /event COMP Nadya treated patient which refused prinimat' lekarstva], ona ${ }_{1}$ vspominala $t_{2}$ včera. to.take medicine she remembered yesterday 'Nadya ${ }_{1}$ remembered a rumor /an event that she ${ }_{1}$ treated the patient who refused to take medicine yesterday.'

\section{$3 \quad \llbracket$ Cont-CP $\rrbracket \neq \llbracket$ Sit-CP $\rrbracket$}

If we want CPs to combine with Cont-DPs (10) as modifiers, we cannot treat them as denoting propositions $(1 \mathrm{a})=(11)$. Predicate Modification either will not be able to combine (10) and (11) due to a type mismatch (if we assume distinct types for individuals and situations), or will return a wrong meaning - an empty set.

(10) $\llbracket$ idea $\rrbracket=\{x: x$ is an idea $\}$

(11) 【that the squirrels ate the nuts $\rrbracket=\{\mathrm{s}$ : the squirrels ate the nuts in $\mathrm{s}\}$

Viewing CPs as predicates of things with propositional content (Moltmann 1989, 2014; Kratzer 2006, 2016; Moulton 2009, 2015; Elliott 2017), (1c)=(12), will allow us to combine embedded clauses with nouns via Predicate Modification (13).

(12) 【that the squirrels ate the nuts $\rrbracket=$ $\lambda \mathrm{x} \in \mathrm{D}_{e} . \operatorname{Cont}(\mathrm{x})=\{\mathrm{s}$ : the squirrels ate the nuts in $\mathrm{s}\}$ 
【idea that the squirrels ate the nuts $\rrbracket=$ $\lambda \mathrm{x} \in \mathrm{D}_{e} . \operatorname{idea}(\mathrm{x}) \wedge \operatorname{Cont}(\mathrm{x})=\{\mathrm{s}$ : the squirrels ate the nuts in $\mathrm{s}\}$

The question that arises then is whether (12) can also be the denotation of CPs that combine with Sit-DPs. I suggest a negative answer to this question. If Sit-CPs described content, then Sit-DPs would have to denote entities that have content. A characteristic feature of such entities is their ability to combine with predicates like 'true', 'false', 'mistaken' (Moulton 2009; Elliott 2017; Moltmann 2020). However, Sit-DPs are incompatible with such predicates, as is shown in (14).

(14) Ideja /*situacija [ ${ }_{C P}$ čto grjadut reformy] javljaetsja vernoj idea /situation COMP are.coming reforms is true /ošibočnoj.

/mistaken

'An idea / a situation that reforms are coming is true / mistaken.'

Thus, Sit-DPs do not denote entities with content, and Sit-CPs cannot have the meaning in (12). In contrast, only Sit-DPs combine with verbs like 'occur' and 'happen' (15), suggesting that they denote situations that CPs describe.

Včera proizošla /slučilas’ *ideja /situacija [ ${ }_{C P}$ čto moj zakaz yesterday occured /happened idea/situation COMP my order zaderžali]. delayed

'Yesterday a situation / idea that my order was delayed happened /occurred.'

What we see then is that the embedded proposition can be related to the meaning of a DP in two different ways. With a Cont-DP, the embedded proposition describes the propositional content associated with the individual denoted by the DP, whereas with a Sit-DP, it describes the situation denoted by the DP.

This difference in meaning is further reinforced by another distinction: while Cont-CPs constitute a referentially opaque domain, Sit-CPs are referentially transparent (Barwise 1981; Higginbotham 1983). ${ }^{2}$

$$
\text { Lena noticed Cont-DP } \underbrace{[C P \text {..DP.. }]}_{\text {opaque }}
$$

(17)

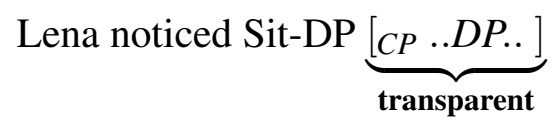

One way to see this distinction is to apply the substitution test. With Cont-DPs like slux 'rumor', from the premises in (18a) and (18b) the conclusion in (18c) does not follow: one can truthfully assert (18a) and (18b) and negate (18c). If Lena noticed a

2 Cf. also the actuality condition in (Moltmann 2021). 
The dual life of embedded CPs

rumor that this woman arrived on a horse, it doesn't follow that she noticed a rumor that the queen arrived on a horse, even if this woman on a horse is the queen.
a. Lena zametila slux /slučaj [čto èta ženščina priexala na kone]. Lena noticed rumor /event COMP this woman arrived on horse 'Lena noticed a rumor /an event that this woman arrived on a horse.'
b. èta ženščina - [koroleva Velikobritanii]. this woman queen Great.Britain
'This woman is the queen of Great Britain.'
c. Lena zametila slux /slučaj [čto [koroleva Velikobritanii] priexala Lena noticed rumor /event COMP queen Great.Britain arrived na kone]. on horse

'Lena noticed a rumor /an event that the queen of G.B. arrived on a horse.'

With Sit-DPs like slučaj 'event' on the other hand, the premises in (18a) and (18b) necessitate the truth of the conclusion in (18c). If Lena noticed an event of this woman arriving on a horse, then she must have seen an event of the queen arriving on a horse if this woman is the queen (even if Lena didn't know this).

Another manifestation of the difference in referential opacity/transparency comes from the availability of de dicto readings. Because Cont-CPs are referentially opaque, DPs inside of them can receive both de re and de dicto readings, and thus sentences like (19), which require us to interpret one of the DPs as de re and the other as de dicto, are felicitous.

(19) Andreja pozabavilo (ošibočnoe) mnenie, [čto [ovcy na ètoj gore] Andrej amused (mistaken) opinion COMP sheep on this mountain èto kozy]. COP goats

'A(n) (mistaken) opinion that the sheep on this mountain are goats amused Andrej.'

Because Sit-CPs are referentially transparent, DPs inside of them lack the ability to be interpreted de dicto, and thus sentences like (20) are infelicitous under the assumption that it is impossible to be a sheep and a goat at the same time.

(20) \#Andreja pozabavila situacija, [čto [ovcy na ètoj gore] - èto kozy]. Andrej amused situation COMP sheep on this mountain COP goats

'A situation that the sheep on this mountain are goats amused Andrej.' 
To sum up, we have seen that CPs that combine with Cont-DPs describe their propositional content, and these CPs are referentially opaque, whereas CPs that combine with Sit-DPs describe situations, and these CPs are referentially transparent. Thus, despite having the same morphosyntactic appearance, Cont-CPs and Sit-CPs cannot have identical denotations.

\section{Proposal}

I adopt Kratzer's (1989; 2020) situation semantics and also assume that situations form a subset of the indiviuals $\left(\mathrm{D}_{s} \subset \mathrm{D}_{e}\right){ }^{3}$ I propose that the meaning of čto-clauses depends on the interpretation of the argument that they modify. The complementizer čto denotes a function that takes a proposition and an individual $\mathrm{x}$ (which could in principle be a situation) as its arguments, and the conditions for this function returning 1 or 0 depend on the properties of $x(21)$.

$$
\begin{aligned}
& \llbracket \check{c} t o \rrbracket=\lambda \mathrm{p} \in \mathrm{D}_{\text {st }} . \lambda \mathrm{x} \in \mathrm{D}_{e} . \\
& \begin{cases}\operatorname{Cont}(\mathrm{x})=\mathrm{p} & x \in \operatorname{dom}(\text { Cont }) \\
\mathrm{x} \text { exemplifies } \mathrm{p} & x \notin \operatorname{dom}(\text { Cont }) \wedge x \in D_{s}\end{cases} \\
&
\end{aligned}
$$

In particular, what matters is whether $\mathrm{x}$ has propositional content associated with it or not. I assume that only a subset of the domain of individuals has propositional content: e.g., individuals like apples and situations like running are not associated with any propositions, whereas individuals like rumors and situations like thinking are. We can say that Cont is a partial function from the domain of individuals to the domain of propositions, and dom(Cont) is the domain of individuals with content.

Then if the second argument of čto is an individual with propositional content, the condition for the function denoted by čto returning 1 is that the result of applying the Cont function to $\mathrm{x}$ is the embedded proposition (Kratzer 2006; Moulton 2015; Elliott 2017), which in situation semantics is a set of situations (22).

$$
\llbracket[T P \text { belki s"eli orexi }] \rrbracket=\{\mathrm{s} \mid \text { the squirrels ate the nuts in } \mathrm{s}\}
$$

If however the second argument of čto is not in the domain of the Cont function, but it is a situation, then the condition for the function denoted by čto returning 1 is that $\mathrm{x}$ exemplifies the embedded proposition. Exemplification is a relation between a situation and a proposition with the definition in (23).

(23) Exemplification (based on Kratzer (1989, 2002); Deigan (2020))

$$
\begin{aligned}
& \mathrm{s} \text { exemplifies } \mathrm{p}=\operatorname{def} \\
& \mathrm{s} \in \mathrm{p} \wedge\left(\forall \mathrm{s}^{\prime}\left[\mathrm{s}^{\prime} \sqsubset \mathrm{s} \Rightarrow \mathrm{s}^{\prime} \in \mathrm{p}\right] \quad \vee \quad \forall \mathrm{s}^{\prime}\left[\mathrm{s}^{\prime} \sqsubset \mathrm{s}^{\prime} \Rightarrow \mathrm{s}^{\prime} \notin \mathrm{p}\right]\right)
\end{aligned}
$$

3 This ontological assumption is made, for example, in (Portner 1992). 
A situation $\mathrm{s}$ exemplifies a proposition $\mathrm{p}$ if $\mathrm{p}$ is true in $\mathrm{s}$ and the proper parts of $\mathrm{s}$ are homogeneous with respect to $\mathrm{p}$ : either in all of them $\mathrm{p}$ is true, or in none of them $\mathrm{p}$ is true. This definition allows us to have exemplifying situations for propositions like There is mud or Achilles is moving, for which it is not clear that there can be a minimal situation in which they are true.

When the complementizer čto combines with the embedded proposition (by Functional Application) and with the noun (by Predicate Modification), we get the following meanings for Cont-DPs and Sit-DPs like in (3) and (4) respectively:

【mysl' čto belki s"'eli orexi $\rrbracket=$ $\lambda x$. thought $(x) \wedge \operatorname{Cont}(x)=\left\{s^{\prime} \mid\right.$ the squirrels ate the nuts in s' $\}$

【slučaj čto belki s"eli orexi》= $\lambda$ s. event(s) $\wedge$ s exemplifies $\left\{s^{\prime} \mid\right.$ the squirrels ate the nuts in s' $\}$

In (24) the CP's meaning is as in (1c), and we get a set of thoughts whose propositional content is the set of situations in which the squirrels ate the nuts. In (25) we have a set of situations that are events which exemplify the proposition The squirrels ate the nuts. Due to situations of the squirrels eating the nuts not being divisive (their proper parts are not situations of the squirrels eating the nuts), the denotation of (25) is a set of minimal situations that are events of the squirrels eating the nuts. Thus, the meaning for the $\mathrm{CP}$ in (25) is as in (1b).

\subsection{Capturing the observed properties of čto-clauses}

Let us consider how the proposed analysis captures the properties of čto-clauses that we observed in sections 2 and 3. First, on my account CPs are always predicates of individuals which combine with both Cont-DPs and Sit-DPs by Predicate Modification. This sits well with the modifier-like syntactic behavior that we observed in section 2: their optionality, adjunct-like morphosyntax (absence of the genitive demonstrative), and ability to be late-merged to the nouns they combine with.

Second, according to my proposal čto-clauses do not always describe propositional content. Thus, they combine with nouns that lack it (predicates of situations). They also do not always describe situations. Thus, they can occur with more abstract nouns which are incompatible with predicates like 'occur' or 'happen'.

Finally, in section 3 we saw that Cont-CPs are referentially opaque while SitCPs are referentially transparent. Here is how my proposal predicts this contrast. Consider first the interpretation that we get for a sentence like in (19):

$$
\begin{aligned}
& \llbracket \text { An opinion that the sheep are goats amused Andrej } \rrbracket^{s_{0}}= \\
& \exists \mathrm{s}, \mathrm{x} \text { [amused(s)(Andrej) } \wedge \mathrm{s} \sqsubseteq \mathrm{s}_{0} \wedge \text { Causer }(\mathrm{s})=\mathrm{x} \wedge \text { opinion }(\mathrm{x})\left(\mathrm{s}_{0}\right) \\
& \left.\wedge \operatorname{Cont}(\mathrm{x})=\left\{\mathrm{s}^{\prime}: \text { sheep in } \mathrm{s}_{0} \text { are goats in s' }\right\}\right]
\end{aligned}
$$


In (19) we are evaluating the sentence with respect to a maximal situation $\mathrm{s}_{0}(=$ world), and thus the situation of amusement $s$ is part of $s_{0}$ and the world variable of the predicate 'opinion' is evaluated at $\mathrm{s}_{0}$. The Cont function that comes from the meaning of the complementizer creates an intensional context, and thus the goathood in (19) is not evaluated with respect to $s_{0}$, but with respect to the situations that Cont returns when applied to the argument $\mathrm{x}$. This of course does not preclude some of the predicates within the embedded clause-e.g., such as 'sheep' in (19)— to be evaluated at $\mathrm{s}_{0}$. Thus, Cont-CPs constitute a referentially opaque context, in which de re /de dicto ambiguities are predicted to exist.

Now let us consider Sit-CPs. By definition of exemplification (23), if a situation $\mathrm{s}$ exemplifies $\mathrm{p}$, then $\mathrm{s} \in \mathrm{p}$. Now consider the semantics we get for the infelicitous sentence with a Sit-CP in (20) under the assumption that 'sheep' is evaluated at $\mathrm{s}_{0}$ :

$$
\begin{aligned}
& \llbracket \text { A situation that the sheep are goats amused Andrej } \rrbracket^{s 0}= \\
& \# \exists \mathrm{s}, \mathrm{s}^{\prime}\left[\text { amused(s)(Andrej) } \wedge \mathrm{s} \sqsubseteq \mathrm{s}_{0} \wedge \text { Causer(s) }=\mathrm{s}^{\prime}\right. \\
& \left.\wedge \text { situation(s') } \wedge \mathrm{s}^{\prime} \sqsubseteq \mathrm{s}_{0} \wedge \mathrm{s}^{\prime} \text { exemplifies }\left\{\mathrm{s}^{\prime}: \text { sheep in } \mathrm{s}_{0} \text { are goats in s" }\right\}\right]
\end{aligned}
$$

Due to the definition of exemplification, $s^{\prime} \in\left\{s^{\prime \prime}\right.$ : sheep in $s_{0}$ are goats in $\left.s^{\prime \prime}\right\}$. The noun 'situation' is not embedded in any intensional context in (27), and so s' is part of the situation of evaluation $\mathrm{s}_{0}: \mathrm{s}^{\prime} \sqsubseteq \mathrm{s}_{0}$. This implies that not only sheephood, but also goathood in (20) is evaluated at $\mathrm{s}_{0}$. This means that without further embedding in an intensional context, de re /de dicto ambiguities will not be possible with Sit-CPs and they will be referentially transparent, leading to infelicity of sentences like (20) that require two predicates to be evaluated at different worlds.

The reasoning outlined above also provides an explanation for the fact that the substitution test fails with Cont-CPs, but succeeds with Sit-CPs (18). The object of a predicate like 'notice' is an actual individual in the world of evaluation $\mathrm{s}_{0}$. Thus, if the object is a situation s' $\sqsubseteq \mathrm{s}_{0}$, then if s' is a situation of this woman arriving on a horse, and in $\mathrm{s}_{0}$ this woman is the queen of Great Britain, then s' is a situation of the queen of Great Britain arriving on a horse. Things are different when objects of verbs like 'notice' are individuals like 'rumor'. The fact that 'rumor' is evaluated at $\mathrm{s}_{0}$ does not tell us anything about how predicates inside of the embedded clause have to be evaluated, because the Cont function inside Cont-CPs creates an intensional context. Thus, it is possible to interpret DPs 'this woman' and 'the queen of Great Britain' de dicto, and then the substitution test fails: it is consistent to assert both premises and negate the conclusion.

\subsection{Evidence for exemplification}

In this section I would like to compare the exemplification semantics for Sit-CPs that I proposed (21) to an alternative non-minimal semantics for Sit-CPs: 
The dual life of embedded CPs

(28) $\llbracket\left[\mathrm{SitCP}_{\mathrm{it}}\right.$ that the squirrels ate the nuts $] \rrbracket=\lambda \mathrm{s}$. the squirrels ate the nuts in $\mathrm{s}$.

The denotation in $(28)=(1 \mathrm{a})$ is the denotation of a proposition in situation semantics. The set that the function in (28) characterizes includes situations of different sizes: minimal situations of the squirrels eating the nuts, whole worlds containing such situations, as well as many situations of intermediate sizes-e.g., situations in which the squirrels ate the nuts and the blue jays ate the seeds, but nothing else happened. The question that arises then is whether we could use (28) instead of the exemplification semantics. Are there any reasons to use exemplification?

I would like to argue that we need exemplification for the meaning of Sit-CPs. The first argument in favor of exemplification semantics comes from Sit-DPs that occur as Causers of emotive states. Consider (29).

(29) Context: Sveta won an award and didn't thank anyone when receiving it. Lena was expecting Sveta to win the award, but was surprised that she didn't thank anyone.

[FALSE] Situacija, čto Sveta vyigrala premiju, udivila Lenu. situation COMP Sveta won award surprised Lena

'A situation that Lena won the award surprised Lena.'

The context of (29) makes a situation in which Sveta won and did not thank anyone salient, and this situation surprised Sveta. However, the sentence in (29) is judged false in this scenario: the Sit-DP in this case cannot pick out the situation in which Sveta won and did not thank anyone. Why cannot it?

Let us consider the predictions that the non-minimal semantics (30) and the exemplification semantics make, sketched out in (30) and in (31) respectively.

(29) on the non-minimal semantics for Sit-CPS

$\exists \mathrm{s}[\operatorname{situation}(\mathrm{s}) \wedge \operatorname{surprise}(\mathrm{L})(\mathrm{s}) \wedge \underbrace{\left.s \in\left\{\mathrm{s}^{\prime} \mid \mathrm{S} \text {. won an award in } \mathrm{s}^{\prime}\right\}\right]}$

s could be a situation in which Sveta won an award and didn't thank anyone

(31) (29) on the exemplification semantics for Sit-CPs

$\exists \mathrm{s}[\operatorname{situation}(\mathrm{s}) \wedge \operatorname{surprise}(\mathrm{L})(\mathrm{s}) \wedge \underbrace{\left.\mathrm{s} \text { exemplifies }\left\{\mathrm{s}^{\prime} \mid \mathrm{S} \text {. won an award in s' }\right\}\right]}$ s cannot be a situation in which Sveta won an award and didn't thank anyone

The non-minimal semantics for Sit-CPs predicts the sentence in (29) to be true in the provided context (30). There is indeed a situation in which Sveta won an award that surprised Lena-that is the situation in which Sveta won an award and didn't thank anyone. Nothing prevents $s$ in (30) from refering to that situation.

The exemplification semantics for Sit-CPs on the other hand predicts the sentence in (29) to be false. The situation s in which Sveta won an award and didn't 
thank anyone does not exemplify $\left\{\mathrm{s}^{\prime} \mid\right.$ Sveta won an award in s' $\}$. This is so because s contains both a Sveta-winning-award situation and a Sveta-not-thanking-anyone situation as its proper parts. This makes s non-homogeneous with respect to the proposition $\left\{\mathrm{s}^{\prime} \mid\right.$ Sveta won an award in s' $\}$ (it has proper parts in which the proposition is true, and proper parts in which it is false), and thus by the definition of exemplification in (23) s does not qualify as this proposition's exemplifier. And given that in the provided context Lena was not surprised by a situation that exemplifies Sveta winning an award (she was only surprised by a bigger situation that contains it), (29) is correctly predicted to be false.

Thus, the exemplification semantics has advantage over the non-minimal semantics in being able to capture the interpretation of sentences like (29). The second argument in favor of exemplification comes from the ban on stacking. Modifiers of nouns can usually be stacked, but only one CP is able to modify a Sit-DP:

$$
\begin{aligned}
& \text { * situacija [čto Mitja igral na pianino] [čto Nastja pela] } \\
& \text { situation COMP Mitya played on piano COMP Nastya sang } \\
& \text { 'a situation, in which Mitya played a piano, in which Nastya sang' }
\end{aligned}
$$

This is unexpected under the non-minimal semantics for Sit-CPs: nothing prevents several CPs from combining with the noun by Predicate Modification and shrinking the set of situations in the predicate a bit (33).

$$
\lambda \mathrm{s} \text {. situation(s) } \wedge \text { Mitya played a piano in } s \wedge \text { Nastya sang in } s
$$

The ban on stacking is however predicted by the exemplification semantics. There can be no single situation that exemplifies both $\left\{\mathrm{s}^{\prime}\right.$ : Mitya played a piano in s' $\}$ and \{s': Nastya sang in s'\}, and thus the meaning of stacked Sit-CPs will always result in an empty set (34), which I assume is the cause of the ungrammaticality. ${ }^{4}$

$$
\begin{aligned}
& \lambda s . \text { situation }(s) \wedge s \text { exemplifies }\left\{s^{\prime}: \text { Mitya played a piano in } s^{\prime}\right\} \\
& \wedge \text { s exemplifies }\left\{s^{\prime}: \text { Nastya sang in } s^{\prime}\right\}=\emptyset
\end{aligned}
$$

One more argument in favor of exemplification comes from the ban on modifying deverbal nouns. It is plausible to think that deverbal nouns like kormlenie životnyx 'feeding of animals' denote predicates of situations, and thus we might expect SitCPs to combine with them by Predicate Modification. However, this does not seem to be possible: a relative clause needs to be used instead of a čto-clause to convey the desired meaning, (35)-(36).

4 The exemplification semantics however does not exclude stacking of Sit-CPs with completely identical propositions in them (situation that $p$ that $p$ ). I have to assume that some independent constraint on redundancy rules out those cases as ungrammatical. 
The dual life of embedded CPs

* kormlenie životnyx [čto belki s"eli orexi] feeding of.animals COMP squirrels ate nuts

'feeding of the animals in which the squirrels ate the nuts'

kormlenie životnyx [pri kotorom belki s"eli orexi]

feeding of.animals by REL squirrels ate nuts

'feeding of the animals in which the squirrels ate the nuts'

I would like to suggest that this contrast can be understood if we assume that deverbal nominals are predicates of situations that exemplify the underlying proposition:

$\llbracket$ feeding animals $\rrbracket=\lambda s$. s exemplifies $\left\{s^{\prime}: s^{\prime}\right.$ is a feeding of animals $\}$

If (37) is correct, then exemplification semantics predicts (35) to be ungrammatical for the same reason that stacking CPs is disallowed: intersecting two sets of situations which exemplify different propositions is impossible (38).

(35) on the exemplification semantics for Sit-CPs

[feeding animals that the squirrels ate the nuts $\rrbracket=\lambda \mathrm{s}$. $\mathrm{s}$ exemplifies $\left\{\mathrm{s}^{\prime}: \mathrm{s}^{\prime}\right.$ is a feeding of animals $\} \wedge$ s exemplifies $\left\{s^{\prime}\right.$ : the squirrels ate the nuts in $\left.s^{\prime}\right\}=\emptyset$

Any situation that exemplifies the squirrels eating the nuts doesn't include any feeding. And feeding is included in all situations that exemplify feeding animals, and thus (38) is always an empty set, hence the ungrammaticality of (35).

The non-minimal semantics on the other hand incorrectly predicts a reasonable meaning for (35): the set of exemplifying animal-feeding situations is just further restricted to the ones in which the squirrels eat nuts (39).

(35) on the non-minimal semantics for Sit-CPs

$\llbracket$ feeding animals that the squirrels ate the nuts $\rrbracket=\lambda$ s. s exemplifies

$\left\{s^{\prime}: s^{\prime}\right.$ is a feeding of animals $\} \wedge$ the squirrels ate the nuts in $s$

The grammaticality of (36) suggests that relativization differs from complementation in that it does not involve exemplification. Thus, while the semantics in (39) is incorrect for the attempts to combine deverbal nouns with čto-clauses, it might be exactly right for cases where deverbal nouns are modified by relative clauses (36).

To sum up, in this section I argued that when čto-clauses combine with nouns, their meaning is sensitive to the meaning of the noun that they modify: they describe the propositional content of the nominal argument when they combine with ContDPs, and they specify the proposition that the situation exemplifies when they combine with Sit-DPs. This accounts for the properties in which Cont-CPs and SitCPs differ, e.g., while the former are referentially opaque, the latter are transparent. In the next two sections I will show that čto-clauses lead the same dual life when they combine with verbs, and that we might be able to decompose the disjunctive meaning for the complementizer in (21) into two separate pieces. 


\section{Cont-CPs and Sit-CPs with verbs}

We have only seen evidence for distinguishing Cont-CPs and Sit-CPs for the clauses that combine with nouns, but there are also reasons to believe that the same two meanings of CPs are attested when clauses combine with verbs.

CPs that combine with verbs have been analyzed as predicates of contentful entities in the literature: sometimes as modifiers of internal arguments of verbs (Kratzer 2006, 2016; Moulton 2015), sometimes as modifiers of event arguments (Bogal-Allbritten 2016, 2017; Elliott 2017). CPs that combine with verbs like dumat' 'think', somnevatsja 'doubt' or predpolagat' 'assume' are Cont-CPs: they describe the propositional content associated with some contentful individual (e.g., thought) or state (e.g., state of thinking), and are referentially opaque, as is illustrated by the felicity of (40), in which the DP 'goats' is interpreted de dicto.

(40) Maša dumaet/somnevaetsja/predpolagaet čto ovcy èto kozy.

Masha thinks /doubts /assumes COMP sheep COP goats

'Masha thinks /doubts /assumes that the sheep are goats.'

But there are also verbs that take Sit-CPs. In Russian these are verbs like byvat' 'happen', slučatsja 'occur', proisxodit' 'take place'. When CPs combine with these verbs, they describe situations that happen /occur /take place. These CPs are referentially transparent. In (41) we see that the sentence that requires the predicate 'goats' within the embedded clause to be interpreted de dicto is infelicitous with these verbs (assuming that no individual can both be a sheep and a goat).

\# Byvaet /slučilos'/proizošlo (takoe) čto ovcy èto kozy. happens /occured /took.place (such) COMP sheep COP goats

lit. 'It happens /occured /took place that sheep are goats.'

(42) shows that the substitution test succeeds with these CPs: if situations of this woman riding on a horse happen in the world of evaluation $\mathrm{s}_{0}$, then provided this woman is the queen of Great Britain in $s_{0}$, it follows that situations of the queen of Great Britain riding on a horse happen in $\mathrm{s}_{0}$.

a. Byvaet (takoe) čto èta ženščina ezdit na kone. happens (such) COMP this woman rides on horse

'It happens that this woman rides a horse.'

b. èta ženščina - [koroleva Velikobritanii].

this woman queen Great.Britain

'This woman is the queen of Great Britain.' 
The dual life of embedded CPs

\section{c. Byvaet (takoe) čto koroleva Velikobritanii ezdit na kone. happens (such) COMP queen Great.Britain rides on horse 'It happens that the queen of G.B. rides a horse.'}

Thus, we see that with verbs as well as with nouns, the interpretation of the čto-clause depends on what it combines with. If we think that čto-clauses modify an argument of the verb, then we can assume that whether they will be interpreted as Cont-CPs or Sit-CPs depends on the properties of the verb's argument-on whether it is an entity in the domain of the Cont function, or a situation that's not.

Russian has an additional morphosyntactic diagnostic for distinguishing ContCPs from Sit-CPs with verbs which tracks the distinction in referential transparency: Sit-CPs can occur with an optional modifier takoe 'such' (43), Cont-CPs can't (44).

Slučilos’ /proizošlo (takoe) čto belki s"eli vse orexi. occured /happened (such) COMP squirrels ate all nuts

lit. 'That the squirrels ate all the nuts occured /happened.'

$$
\begin{aligned}
& \text { * Maša dumaet /somnevaetsja takoe čto belki s"eli vse orexi. } \\
& \text { Masha thinks /doubts such COMP squirrels ate all nuts } \\
& \text { 'Masha thinks /doubts that the squirrels ate all the nuts.' }
\end{aligned}
$$

We have seen that there are verbs like dumat' 'think' that select for Cont-CPs and verbs like slučatsja 'occur' that select for Sit-CPs, which raises the question of whether there are verbs that admit CPs with both interpretations. I would like to suggest that verbs like pomnit' 'remember', zamečat' 'notice', videt' 'see' are such verbs, although the distinction is harder to see due to their (semi-)factivity. These verbs can combine with takoe 'such' (45), and when they do, direct perception reports are created, just as with a designated direct perception complementizer kak.

$$
\text { Lena pomnit } \quad\{\text { takoe čto }\} / / \text { kak }\} \quad \text { Mitja kuril. }
$$

Lena remembers such COMP/COMP.DIRECT Mitya smoked

'Lena remembers M.'s smoking.' $\Rightarrow$ Lena directly perceived M. smoking.

We can think of (45) as 'remember' combining with a Sit-CP: a situation that exemplifies $\left\{\mathrm{s}^{\prime}\right.$ : Mitya smokes in s'\} is what is remembered by Lena. Without modification by takoe 'such', there is no direct perception requirement:

Lena pomnit (to) čto Mitja kuril, xot' ona i ne Lena remembers (that.DEM) COMP Mitya smoked though she CONJ NEG videla ego ni razu kurjaščim.

saw him not once smoking

'Lena remembers the fact that Mitya smoked, despite not seeing him smoke even once.' $\nRightarrow$ Lena directly perceived Mitya smoking. 
We can think of (46) as 'remember' combining with a Cont-CP: the fact or claim $\mathrm{x}$ whose content is the proposition $\left\{\mathrm{s}^{\prime}\right.$ : Mitya smokes in s' $\}$ is what is remembered by Lena. In this case there doesn't have to be any direct relation between Lena and a situation of Mitya smoking. ${ }^{5}$

To sum up, CPs that combine with verbs differ in their interpretation, and these differences can be viewed as stemming from the restrictions that verbs place on the arguments that CPs modify. Some verbs (like dumant' 'think') require that their arguments are in dom(Cont), others (like slučatsja 'occur') take situations as their arguments, and there are also verbs (like pomnit' 'remember') which do not place any restrictions and thus can combine with both Cont-CPs and Sit-CPs.

\section{Comparison with Korean: an argument for decomposition}

The meaning for the complementizer that I proposed in (21) is disjunctive in nature, which raises the questions of whether it is possible to dissociate the introduction of the Content function from the rest of the lexical entry, and whether there is any evidence for such a decomposition. Here is how the decomposition could look like. It could be the case that the structure of Cont-CPs contains a phonologically null projection ContP (47) which the structure of Sit-CPs lacks (48).

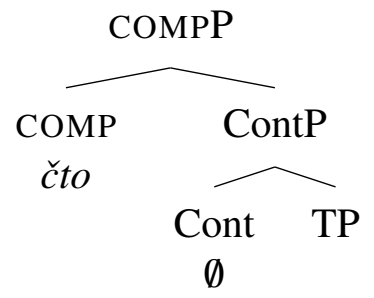

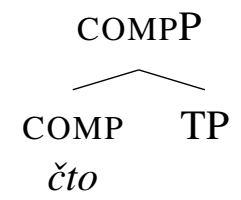

Then if we assume that exemplification is defined not only for situations, but for all individuals, we can attribute Cont and COMP the meanings in (49) and (50).

$$
\begin{aligned}
& \llbracket \text { Cont } \rrbracket=\lambda \mathrm{p}_{s t} \cdot \lambda \mathrm{x}_{e} \cdot \operatorname{Content}(\mathrm{x})=\mathrm{p} \\
& \llbracket \operatorname{COMP} \rrbracket=\lambda \mathrm{p}_{e t} \cdot \lambda \mathrm{x}_{e} \cdot \mathrm{x} \text { exemplifies } \mathrm{p}
\end{aligned}
$$

The denotation of the Cont-DP in (3), for example, then will be as in (51): a set of individuals that are thoughts and which exemplify the predicate of individuals with propositional content $\left\{\mathrm{s}^{\prime} \mid\right.$ squirrels ate the nuts in s'\}.

5 This account predicts that verbs like pomnit' 'remember' should be referentially transparent if the clause they combine with is understood as a Sit-CP, but referentially opaque if the clause they combine with is interpreted as a Cont-CP. I leave testing this prediction for the future. 
The dual life of embedded CPs

【mysl' [čto CONT belki s"eli vse orexi] $]=\lambda \mathrm{x}$. thought $(\mathrm{x}) \wedge \mathrm{x}$ exemplifies $\left\{y \mid \operatorname{Cont}(y)=\left\{s^{\prime} \mid\right.\right.$ the squirrels ate all the nuts in s' $\left.\}\right\}$

This differs from the previous semantics in (24) only in the addition of the exemplification requirement, which does not contribute anything, but as far as I can tell is harmless. ${ }^{6}$ The denotation of the Sit-DP in (4) will be as in (52), which is exactly the meaning we had before (25).

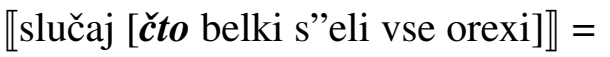

$\lambda \mathrm{s}$. event(s) $\wedge \mathrm{s}$ exemplifies $\left\{\mathrm{s}^{\prime} \mid\right.$ the squirrels ate all the nuts in $\left.\mathrm{s}^{\prime}\right\}$

Having seen that decomposition is in principle possible, we can now ask whether there is any empirical evidence for it actually taking place. While I have not been able to find such evidence within Russian, Korean seems to provide support for the decompositional analysis. Both Cont-CPs and Sit-CPs that combine with nouns in Korean are clauses with the so-called adnominal marker -(n)un (see Kim 2009, Lee 2019, a.o., for discussion of these clauses in other constructions). However, the two types of clauses differ in their internal structure: the so-called declarative marker - $t a$ has to occur in the structure of Cont-CPs (53), but cannot occur in Sit-CPs (54). ${ }^{7}$

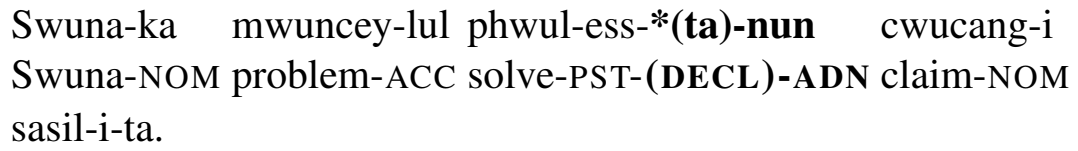

'The claim that Swuna solved the problem is a fact.'

[Swuna-ka mwuncey-lul phwul-(*ta)-un] sanghwang-i Swuna-NOM problem-ACC solve-(DECL)-ADN situation-NOM hungmilop-ta interesting-DECL

'The situation that Swuna solved the problem is interesting.'

We can hypothesize then that Korean allows us to see the underlying structure: perhaps Korean declarative marker $-t a$ is the spell-out of the Cont head and the adnominal marker $-(n) u n$ is the exponent corresponding to COMP: ${ }^{8}$

6 But it has an interesting consequence: for an individual $\mathrm{x}$ with propositional content $\mathrm{p}$ it is required that either no proper parts of $\mathrm{x}$ also have content $\mathrm{p}$, or that all proper parts of $\mathrm{x}$ have content $\mathrm{p}$. More research into the mereological structure of contentful individuals is required to test this prediction.

7 There is another difference between them: in (53) we see the past tense marker -ess that is absent in (54). However, this restriction on the presence of -ess is not absolute: for example, -ess is able to occur in the first conjunct if two propositions are conjoined (by conjunction ko) under a Sit-DP. Further research is necessary to determine the distribution of -ess in these clauses.

$8-T a$ also occurs in matrix clauses, raising the question of whether it has the same meaning in them. 
Bondarenko

(55)

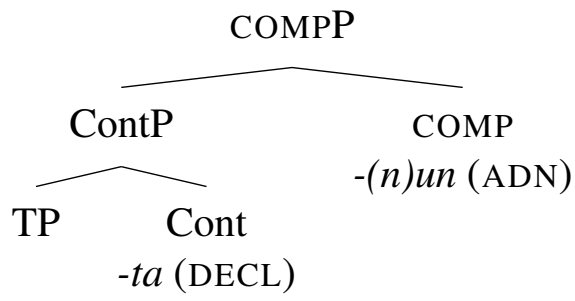

(56)

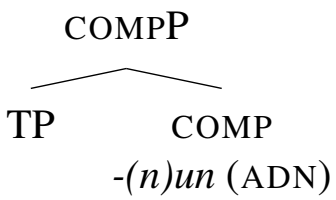

This analysis makes the following prediction. If it is -ta that creates an intensional context, Cont-CPs should be referentially opaque in Korean, and Sit-CPs should be transparent, just like in Russian. This is borne out, (57)-(58).

a. Mina-ka [Swuna-ka mwuncey-lul phwul-ess-ta-nun] Mina-NOM Swuna-NOM problem-ACC solve-PST-DECL-ADN cwucang-ul kiekhay-ss-ta. claim-ACC remember-PST-DECL 'Mina remembered the claim that Swuna solved the problem.'

b. Swuna-ka pan-eyse kacang khi-ga khu-ta. Swuna-NOM class-LOC most height-NOM large-DECL

'Swuna is the tallest girl in the class.'

\section{c. $\nRightarrow$ Mina-ka [pan-eyse kacang khi-ga khun sonye-ka Mina-NOM class-LOC most height-NOM large girl-NOM} mwuncey-lul phwul-ess-ta-nun] cwucang-ul kiekhayssta. problem-ACC solve-PST-DECL-ADN claim-ACC remembered 'Mina remembered the claim that the tallest girl in the class solved the problem.'

In (57) we see that Cont-CPs are referentially opaque: from the premises in (57a) and (57b) the conclusion in (57c) does not follow. (58) shows that the substitution test succeeds with Sit-DPs like sanghwang 'situation': if Mina remembers the situation of Swuna solving the problem, then she remembers the situation of the tallest girl in the class solving the problem, provided that Swuna is the tallest girl.

a. Mina-ka [Swuna-ka mwuncey-lul phwul-un] sanghwang-ul Mina-NOM Swuna-NOM problem-ACC solve-ADN situation-ACC kiekhay-ss-ta. remember-PST-DECL

'Mina remembers the situation that Swuna solved the problem.'

b. Swuna-ka pan-eyse kacang khi-ga khu-ta.

Swuna-NOM class-LOC most height-NOM large-DECL

'Swuna is the tallest girl in the class.' 
The dual life of embedded CPs

\section{c. $\Rightarrow$ Mina-ka [pan-eyse kacang khi-ga khun sonye-ka Mina-NOM class-LOC most height-NOM large girl-NOM} mwuncey-lul phwul-un] sanghwang-ul kiekhay-ss-ta. problem-ACC solve-ADN situation-ACC remember-PST-DECL 'Mina remembers that the tallest girl in the class solved the problem.'

Thus, Korean allows us to conclude that different functional pieces are responsible for introducing the Cont function (Cont) and for establishing an exemplification relation (COMP). While the Cont head might lack an overt exponent in some languages (Russian), Korean provides us evidence for its existence.

\section{Concluding remarks}

In this paper I argued that finite embedded clauses can have two distinct meanings: they can either denote sets of individuals whose propositional content equals the embedded proposition (Cont-CPs) or sets of situations that exemplify the embedded proposition (Sit-CPs). While Cont-CPs create an intentional context (and are thus opaque), Sit-CPs are referentially transparent. Both types of CPs can look morphosyntactically the same in a given language (Russian), but data from Korean suggests that their functional make-up is not the same: while both CPs have a complementizer (COMP) that introduces the exemplification relation, only Cont-CPs have a functional head (Cont) that introduces the Content relation.

Here are some implications of this proposal. First, it provides further support for theories of clausal embedding that treat embedded CPs as modifiers rather than arguments (Kratzer 2006; Moulton 2015; Elliott 2017). Second, a consequence of this proposal is that not all finite embedded clauses create intensional contexts. Finally, data from Korean suggests that it's not complementizers, but a functional element lower in the left periphery that is the source of the Content function.

One open question that remains is how much variation we find in whether embedded clauses can occur with Sit-DPs, and what drives such variation. For example, many English speakers find that-clauses to be quite odd with nouns like situation (although some naturally occuring examples can be found, e.g. (59)), and prefer to use in which-clauses or where-clauses instead.

(59) It is [a curious situation that the sea, from which life first arose should now be threatened by the activities of one form of that life]. ${ }^{9}$

What is the cause of this restriction? One hypothesis that could be investigated is that while that-clauses could in principle modify Sit-DPs, they compete with other clauses available in the language and lose on account of some characteristic.

9 https://www.goodreads.com/quotes/24091-it-is-a-curious-situation-that-the-sea-from-which 
Bondarenko

\section{References}

Barwise, Jon. 1981. Scenes and other situations. The Journal of Philosophy 78(7). 369-397. doi:10.2307/2026481.

Bogal-Allbritten, Elizabeth. 2016. Building Meaning in Navajo: University of Massachusetts Amherst PhD dissertation.

Bogal-Allbritten, Elizabeth. 2017. Basic pieces, complex meanings: Building attitudes in Navajo and beyond. Workshop on polysemy and coercion of clause embedding predicates. Talk at the 39th Annual Meeting of the German Linguistics Society (DFfS).

Deigan, Michael. 2020. A plea for inexact truthmaking. Linguistics and Philosophy 43(5). 515-536. doi:10.1007/s10988-019-09279-2.

Elliott, Patrick D. 2016. Explaining DPs vs. CPs without syntax. In The 52nd Chicago Linguistic Society (CLS), vol. 52, 171-185.

Elliott, Patrick D. 2017. Elements of Clausal Embedding: UCL (University College London) $\mathrm{PhD}$ dissertation.

Higginbotham, James. 1983. The logic of perceptual reports: An extensional alternative to situation semantics. The Journal of Philosophy 80(2). 100-127. doi:10.5840/jphil198380289.

Kim, Min-Joo. 2009. E-type anaphora and three types of kes-construction in Korean. Natural Language \& Linguistic Theory 27(2). 345-377. doi:10.1007/s11049009-9065-5.

Knyazev, Mikhail. 2016. Licensing Clausal Complements: The case of Russian Čto-clauses. LOT.

Kratzer, Angelika. 1989. An investigation of the lumps of thought. Linguistics and Philosophy 12(5). 607-653. doi:10.1007/BF00627775.

Kratzer, Angelika. 2002. Facts: Particulars or information units? Linguistics and Philosophy 25(5/6). 655-670. doi:10.1093/acprof:oso/9780199234684.003.0006.

Kratzer, Angelika. 2006. Decomposing attitude verbs. Talk given at the Hebrew University of Jerusalem.

Kratzer, Angelika. 2016. Evidential moods in attitude and speech reports. Talk given at the 1st Syncart Workshop.

Kratzer, Angelika. 2020. Situations in Natural Language Semantics. In Edward N. Zalta (ed.), The Stanford Encyclopedia of Philosophy, Metaphysics Research Lab, Stanford University Fall 2020 edn.

Lebeaux, David. 1991. Relative clauses, licensing, and the nature of the derivation. In Perspectives on Phrase Structure: Heads and Licensing, 209-239. Brill. doi:10.1163/9789004373198_011.

Lee, Chungmin. 2019. Nominals with Factive vs. Non-factive Complements. Seoul National University, ms. 
The dual life of embedded CPs

Moltmann, Friederike. 1989. Nominal and clausal event predicates. In The 25th Chicago Linguistic Society (CLS), vol. 25, 300-314.

Moltmann, Friederike. 2013. Abstract Objects and the Semantics of Natural Language. OUP Oxford.

Moltmann, Friederike. 2014. Propositions, attitudinal objects, and the distinction between actions and products. Canadian Journal of Philosophy 43((5-6)). 679701. doi:10.1080/00455091.2014.892770.

Moltmann, Friederike. 2020. Truthmaker semantics for natural language: Attitude verbs, modals, and intensional transitive verbs. Theoretical Linguistics 46((3-4)). 159-200.

Moltmann, Friederike. 2021. Situations, alternatives, and the semantics of 'cases'. Linguistics and Philosophy 44(1). 153-193. doi:10.1007/s10988-019-09282-7.

Moulton, Keir. 2009. Natural Selection and the Syntax of Clausal Complementation: UMass Amherst PhD dissertation.

Moulton, Keir. 2015. CPs: Copies and compositionality. Linguistic Inquiry 46(2). 305-342. doi:10.1162/LING_a_00183.

Portner, Paul Howard. 1992. Situation Theory and the Semantics of Propositional Expressions: University of Massachusetts Amherst PhD dissertation.

Roberts, Tom. 2020. Argument saturation and intransitive modification: The double life of embedded clauses. Talk at the 51st North East Linguistics Society (NELS), November 6-8, Université du Québec à Montréal.

Srinivas, Sadhwi \& Geraldine Legendre. 2020. Deverbal content nominals can select clausal arguments: Evidence from Kannada and English light verb constructions. Talk given at BCGL 13.

Stowell, Timothy Angus. 1981. Origins of Phrase Structure: Massachusetts Institute of Technology, Cambridge, MA PhD dissertation.

Tatiana Bondarenko

32 Vassar Street

Massachusetts Institute of Technology

Cambridge, USA, 02139

tbond@mit.edu 